\title{
Can Glucose-Insulin-Potassium Prevent Skeletal Muscle Ischemia-Reperfusion Injury?
}

\author{
Daniel B Buchalter, David J Kirby, Kenneth A Egol, Philipp Leucht and Sanjit R Konda* \\ Department of Orthopedic Surgery, NYU Langone Orthopedic Hospital, USA
}

*Corresponding author: Sanjit R Konda, Department of Orthopedic Surgery, NYU Langone Orthopedic Hospital, 301 East 17 th St. New York, NY 10003, USA.

To Cite This Article: Daniel BB, David JK, Kenneth AE, Philipp L, Sanjit RK. Can Glucose-Insulin-Potassium Prevent Skeletal Muscle IschemiaReperfusion Injury?. 2020 - 8(4). AJBSR.MS.ID.001299. DOI: 10.34297/AJBSR.2020.08.001299.

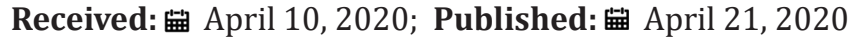

\section{Mini Review}

Extremity injuries cost an estimated $\$ 80$ billion a year [1] and exsanguination is a key factor in fatalities following both civilian and military trauma $[2,3]$. Tourniquets, the primary prevention against extremity exsanguination, and an often used tool in emergent and elective surgeries, are not benign [4]-skeletal muscle apoptosis and necrosis following tourniquet use are common and can lead to limb paralysis, amputation, and even death if rhabdomyolysis and kidney failure occur [5-7]. While muscle does not respond well to ischemia, reperfusion is what causes the most significant damage following tourniquet use in what has been termed the ischemiareperfusion injury $[8,9]$.

Globally, the deadliest ischemia-reperfusion injury is a myocardial infarctio [10]. Preventing muscle damage from myocardial infarctions, through preventing the consequences of the ischemia-reperfusion injury, has been an active area of research in cardiology since heart attacks were described in 1912 [11]. In orthopedics, the prevention of ischemia-reperfusion injury in skeletal muscle has not been as well studied, and to date, no definitive treatments exist $[8,9]$.

One unique treatment in the prevention of myocardial ischemiareperfusion injury following myocardial infarction is glucoseinsulin-potassium (GIK). Since first being tested in the 1960s [1216], several studies have shown that GIK may reduce myocardial Ischemia-reperfusion injury by stabilizing cell membranes $[17,18]$ increasing glycogen content and adenosine triphosphate (ATP) $[19,20]$ reducing free fatty acids (FFA) and reactive oxygen species (ROS) [21,22], and increasing growth hormone/factor production [23-26].

Although several clinical studies have been performed on GIK for cardiac muscle, the recommendations on its use remain mixed. Most large analyses report that it reduces mortality [27-33], while

one found no effect [34], and another found higher mortality with its use [35]. Despite the generally positive results in the cardiac literature, only one study has looked at GIK in skeletal muscle, finding that it reduces glycogen depletion during fasting. However, these authors did not comment on its effect on skeletal muscle ischemia-reperfusion injury [36].

Similar to cardiac muscle, skeletal muscle ischemia-reperfusion injury occurs through ischemic ATP depletion and reperfusionmediated ROS production [37]. ATP depletion destabilizes the electrochemical gradient of the sarcolemma, leading to increased intracellular proteolytic enzymes. Excess ROS increases sarcolemma permeability, and similarly increases intracellular proteolytic enzymes [38]. These enzymes degrade the muscle cell, releasing large quantities of muscle breakdown products including myoglobin, $\mathrm{CK}$, and lactate dehydrogenase that can be nephrotoxic [37]. Since GIK can mitigate these processes in cardiac muscle [1922], it may have some utility in reducing skeletal muscle ischemiareperfusion injury.

Skeletal muscle ischemia-reperfusion injury occurs secondary to several pathologic processes. Traumatic causes, both blunt and sharp, can lead to compartment syndrome, vascular injury, and may require tourniquet use for bleeding control. Iatrogenic causes such as the elective use of tourniquets in upper and lower extremity surgery, vessel re-anastomosis or bypass causing reperfusion, and anticoagulation-related compartment syndrome are also relevant. While these causes differ in frequency and severity, they share a similar pathophysiological pathway that may potentially benefit from GIK. Thus, GIK may play a role in reducing traumatic and 
iatrogenic morbidity and mortality following musculoskeletal injury.

\section{References}

1. (2017) Estimated Number of Extremities Visited to ED and Cost of Injury Reports. Center for Disease Control Prevention.

2. Mabry RL (2006) Tourniquet use on the battlefield. Mil Med. 171(5): 352-356.

3. Inaba K, Siboni S, Resnick S, Zhu J, Wong MD, et al. (2015) Tourniquet use for civilian extremity trauma. J Trauma Acute Care Surg 79(2): 232-237.

4. Welling DR, McKay PL, Rasmussen TE, Rich NM (2012) A brief history of the tourniquet. J Vasc Surg 55(1): 286-290.

5. Kam PC, Kavanagh R, Yoong FF (2001) The arterial tourniquet: pathophysiological consequences and anaesthetic implications. Anaesthesia 56(6): 534-545.

6. Corrick RM, Tu H, Zhang D, Barksdale AN, Muelleman RL, et al. (2018) Dexamethasone Protects Against Tourniquet-Induced Acute IschemiaReperfusion Injury in Mouse Hindlimb. Front Physiol 9: 244.

7. McQueen MM, Gaston P, Court-Brown CM (2000) Acute compartment syndrome. Who is at risk? J Bone Joint Surg Br 82(2): 200-203.

8. Leurcharusmee P, Sawaddiruk P, Punjasawadwong Y, Chattipakorn N, Chattipakorn SC (2018) The Possible Pathophysiological Outcomes and Mechanisms of Tourniquet-Induced Ischemia-Reperfusion Injury during Total Knee Arthroplasty. Oxid Med Cell Longev 2018: 8087598.

9. Halladin NL, Zahle FV, Rosenberg J, Gogenur I (2014) Interventions to reduce tourniquet-related ischaemic damage in orthopaedic surgery: a qualitative systematic review of randomised trials. Anaesthesia 69(9): 1033-1050.

10. Mahase E (2019) Cancer overtakes CVD to become leading cause of death in high income countries. BMJ 366: 15368.

11. Herrick JB (1912) Clinical features of sudden obstruction of the coronary arteries. Journal of the American Medical Association 59(23): 2015-2022.

12. Sodi-PD, Testelli MR, Fishleder BL, Bisteni A, Medrano GA, et al. (1962) Effects of an intravenous infusion of a potassium-glucose-insulin solution on the electrocardiographic signs of myocardial infarction. A preliminary clinical report. Am J Cardiol 9: 166-181.

13. Sievers J, Lindh J, Johansson BW, Karnell J (1966) Acute myocardial infarction treated by glucose-insulin-potassium (GIK) infusion. Cardiologia 49(4): 239-247.

14. Mittra B (1968) Effects of potassium, glucose and insulin therapy on cardiac arrest after myocardial infarction. Ir J Med Sci. 7(8): 373-385.

15. Mittra B (1965) Potassium, glucose, and insulin in treatment of myocardial infarction. Lancet 2(7413): 607-609.

16. Lundman T, Orinius E (1965) Insulin-glucose-potassium infusion in acute myocardial infarction. Acta Med Scand 178(4): 525-528.

17. Nguyen TQ, Maalouf NM, Sakhaee K, Moe OW (2011) Comparison of insulin action on glucose versus potassium uptake in humans. Clin J Am Soc Nephrol 6(7): 1533-1539.

18. Hewitt RL, Lolley DM, Adrouny GA, Drapanas T (1974) Protective effect of glycogen and glucose on the anoxic arrested heart. Surgery 75(1): $1-10$

19. Dimitriadis G, Mitrou P, Lambadiari V, Maratou E, Raptis SA (2011) Insulin effects in muscle and adipose tissue. Diabetes Res Clin Pract 1: 52-59.

20. Doenst T, Bothe $\mathrm{W}$, Beyersdorf $\mathrm{F}$ (2003) Therapy with insulin in cardiac surgery: controversies and possible solutions. Ann Thorac Surg 75(2):
S721-728.

21. Lopaschuk GD, Wambolt RB, Barr RL (1993) An imbalance between glycolysis and glucose oxidation is a possible explanation for the detrimental effects of high levels of fatty acids during aerobic reperfusion of ischemic hearts. J Pharmacol Exp Ther 264(1): 135-144.

22. Schipke JD, Friebe R, Gams E (2006) Forty years of glucose-insulinpotassium (GIK) in cardiac surgery: a review of randomized, controlled trials. Eur J Cardiothorac Surg 29(4): 479-485.

23. Jonassen AK, Sack MN, Mjos OD, Yellon DM (2001) Myocardial protection by insulin at reperfusion requires early administration and is mediated via Akt and p70s6 kinase cell-survival signaling. Circ Res 89(12): 11911198.

24. Ferrando AA, Chinkes DL, Wolf SE, Matin S, Herndon DN (1999) A submaximal dose of insulin promotes net skeletal muscle protein synthesis in patients with severe burns. Ann Surg 229(1):11-18.

25. Gandhi A, Beam HA, O'Connor JP, Parsons JR, Lin SS (2005) The effects of local insulin delivery on diabetic fracture healing. Bone 37(4): 482-490.

26. Thrailkill KM, Lumpkin CK, Bunn RC, Kemp SF, Fowlkes JL (2005) Is insulin an anabolic agent in bone? Dissecting the diabetic bone for clues. Am J Physiol Endocrinol Metab 289(5): E735-745.

27. Fath-Ordoubadi F, Beatt KJ (1997) Glucose-insulin-potassium therapy for treatment of acute myocardial infarction: an overview of randomized placebo-controlled trials. Circulation 96(4): 1152-1156.

28. Diaz R, Paolasso EA, Piegas LS, Tajer CD, Moreno MG, et al. (1998) Metabolic modulation of acute myocardial infarction. The ECLA (Estudios Cardiologicos Latinoamerica) Collaborative Group. Circulation 98(21): 2227-2234.

29. van der Horst IC, Zijlstra F, van 't Hof AW, Doggen CJ, de Boer MJ, et al. (2003) Glucose-insulin-potassium infusion inpatients treated with primary angioplasty for acute myocardial infarction: the glucose-insulinpotassium study: a randomized trial. J Am Coll Cardiol 42(5): 784-791.

30. Selker HP, Beshansky JR, Sheehan PR, Massaro JM, Griffith JL, et al. (2012) Out-of-hospital administration of intravenous glucose-insulinpotassium in patients with suspected acute coronary syndromes: the IMMEDIATE randomized controlled trial. JAMA 307(18): 1925-1933.

31. Selker HP, Udelson JE, Massaro JM, Ruthazer R, D’Agostino RB, et al. (2014) One-year outcomes of out-of-hospital administration of intravenous glucose, insulin, and potassium (GIK) in patients with suspected acute coronary syndromes (from the IMMEDIATE [Immediate Myocardial Metabolic Enhancement During Initial Assessment and Treatment in Emergency Care] Trial). Am J Cardiol 113(10): 1599-1605.

32. Bothe W, Olschewski M, Beyersdorf F, Doenst T (2004) Glucose-insulinpotassium in cardiac surgery: a meta-analysis. Ann Thorac Surg 78(5): 1650-1607.

33. Fan Y, Zhang AM, Xiao YB, Weng YG, Hetzer R (2011) Glucose-insulinpotassium therapy in adult patients undergoing cardiac surgery: a metaanalysis. Eur J Cardiothorac Surg 40(1): 192-199.

34. Diaz R, Goyal A, Mehta SR, Afzal R, Xavier D, Pais P, et al. (2007) Glucoseinsulin-potassium therapy in patients with ST-segment elevation myocardial infarction. JAMA 298(20): 2399-2405.

35. Ceremuzynski L, Budaj A, Czepiel A, Burzykowski T, Achremczyk P, et al. (1999) Low-dose glucose-insulin-potassium is ineffective in acute myocardial infarction: results of a randomized multicenter Pol-GIK trial. Cardiovasc Drugs Ther 13(3):191-200.

36. Reikeras O, Nordstrand K, Henden T (1988) Effects of fasting and glucose-insulin-potassium on glycogen contents in heart, skeletal muscle and liver. Scand J Clin Lab Invest 48(3): 285-288.

37. Carmeli E, Aizenbud D, Rom 0 (2015) How Do Skeletal Muscles Die? An Overview. Adv Exp Med Biol 861: 99-111. 